\title{
Interferon-Containing and Interferon-Free HCV Therapy for HIV-Infected Patients
}

\author{
Mark S. Sulkowski, MD ${ }^{1}$ \\ ${ }^{1}$ Department of Medicine, Johns Hopkins University School of \\ Medicine, Baltimore, Maryland \\ Semin Liver Dis 2014;34:72-78.
}

\begin{abstract}
Address for correspondence Mark S. Sulkowski, MD, Department of Medicine, Johns Hopkins University School of Medicine, 1800 Orleans Street; 1830 Building, Room 445, Baltimore, MD 21287 (e-mail: msulkowski@jhmi.edu).
\end{abstract}

Abstract
Keywords
- human
immunodeficiency
virus
- hepatitis C virus
interferon
- direct-acting
antivirals
- protease inhibitors
- polymerase inhibitors
- NS5A inhibitors

In the era of effective treatment for human immunodeficiency virus (HIV) infection, coinfection with hepatitis $\mathrm{C}$ virus (HCV) is an important cause of morbidity and mortality. Similar to other observations made in other HCV-infected patient populations, treatment of chronic HCV infection that results in sustained virologic response or eradication of the hepatitis infection has been strongly associated with decreased likelihood of end-stage liver disease and/or hepatocellular carcinoma and improved overall survival in HIV-infected patients. However, the effectiveness of HCV treatment has been limited due to frequent contraindications to interferon- $\alpha$ (INF $\alpha$ ) and prior to the advent of HCV direct acting antivirals, relatively low rates of sustained virologic response. Since 2011, the efficacy of HCV treatment in coinfected patients has improved substantially with the addition of HCV direct-acting antivirals to INFa-based regimens. Based on these observations, there is mounting optimism that INFo-free, oral HCV treatments will further improve efficacy, and more importantly, increase access to treatment for many coinfected patients.
Due to shared modes of transmission, hepatitis C virus (HCV) infection is common in persons living with human immunodeficiency virus (HIV) infection. ${ }^{1,2}$ Increasingly, liver disease due to chronic HCV is a major cause of morbidity and mortality in this population and represents a leading cause of death in many settings. ${ }^{3,4}$ Current guidelines recommend that patients with HIV/HCV coinfection undergo HCV treatment with the combination of peginterferon (PegIFN) and ribavirin (RBV). ${ }^{5,6}$ Indeed, on the basis of large randomized controlled trials, the combination of PegIFN $\alpha-2 \mathrm{a}$ and RBV is approved for the treatment of hepatitis $C$ in HIV-infected patients in the United States and other countries. ${ }^{7-9}$ More recently, data from several large prospective longitudinal HIV cohort studies have provided strong evidence that HCV treatment that results in sustained virologic response or cure of chronic HCV infection is associated with decreased risk of end-stage liver disease, hepatocellular carcinoma, and liver-related death. ${ }^{10,11}$

Despite the high burden of HCV disease and the availability of antiviral treatment that has been shown to improve clinical outcomes, few persons with HIV/HCV coinfection have been treated with PegIFN/RBV and even fewer have achieved sustained virological response. ${ }^{12-14}$ For example, less than $10 \%$ of $\mathrm{HIV} / \mathrm{HCV}$ coinfected patients receiving care in the United States Veterans Affairs system have received PegIFN based HCV treatment; in the Johns Hopkins HIV clinic, only $15 \%$ of patients treated with PegIFN/RBV achieved a sustained virologic response. ${ }^{10,15}$ The reasons for the limited effectiveness of PegIFN based HCV treatment in this population include (1) high prevalence of medical (e.g., anemia, acquired immunodeficiency syndrome [AIDS]) and psychiatric (e.g., depression) comorbid conditions in patients with HIV/HCV coinfection that may prevent the safe administration of PegIFN; (2) higher levels of HCV RNA in the blood in patients with HIV infection compared with those without HIV infection; (3) blunted antiviral response to PegIFN in HIV/HCV coinfected patients relative to $\mathrm{HCV}$ monoinfected patients; (4) relatively high incidence of treatment related-adverse effects that impair the ability of HIV/HCV coinfected patients to adhere to prolonged course of IFN and limit the willingness
Issue Theme New Hepatitis C Therapies; Guest Editor, Jean-Michel Pawlotsky, MD, $\mathrm{PhD}$
Copyright @ 2014 by Thieme Medical Publishers, Inc., 333 Seventh Avenue, New York, NY 10001, USA. Tel: +1(212) 584-4662.
DOI http://dx.doi.org/ 10.1055/s-0034-1371012. ISSN 0272-8087. 
of coinfected patients and their HIV care providers to initiate HCV treatment with this drug. ${ }^{16-18}$ Accordingly, more effective and better tolerated HCV treatment regimens represent an important unmet medical need for patients with $\mathrm{HIV} / \mathrm{HCV}$ coinfection.

The expectation is that this urgent medical need will be addressed by many of the multitude of novel HCV antivirals that are in late-stage clinical development. In 2011, the first of these direct-acting antivirals (DAAs), telaprevir and boceprevir, were approved for the treatment of chronic HCV genotype 1 infection in combination with PegIFN/RBV. ${ }^{19,20}$ These oral drugs directly inhibit the HCV NS3/4A protease, leading to potent inhibition of $\mathrm{HCV}$ replication. In 2013, sofosbuvir, a once daily, oral DAA that inhibits the active site of the HCV NS5B polymerase, and simeprevir, a once daily, oral DAA that inhibits the HCV NS3/4A protease, were approved in combination with PegIFN/RBV for the treatment of HCV genotype 1 infection; in addition, sofosbuvir was approved in combination with RBV for the treatment of HCV genotype 2 and 3 infections, heralding the advent of IFN-free therapy for this subset of patients. ${ }^{21,22}$ Further, by 2015, potent, INF-free, combinations of DAAs are expected to become available for the treatment of patients infected with HCV genotypes 1 and $4 .{ }^{23,24}$

Although these IFN-free regimens promise to transform the management of $\mathrm{HCV}$ infection, important questions about their effectiveness in HIV/HCV coinfected patients remain to be answered: 1) Will the antiviral efficacy of these regimens be blunted by HIV infection? 2) Will unanticipated adverse effects emerge in HIV/HCV coinfected patients? 3) Will clinically important drug interactions exist between antiretroviral drugs used to treat HIV infection and direct acting antivirals used to treat HCV infection?

\section{Limited Effectiveness of Interferon Based HCV Treatment in Patients with HIV Infection}

Interferon- $\alpha$ (INF $\alpha$ ) has been used extensively in persons with HIV infection. Prior to the advent of targeted anti-HIV medications, INF $\alpha$ was used to treat HIV infection. In vitro, HIV replication can be inhibited by type I IFNs through the induction of proteins with anti-HIV-1 activity. For example, Kane and coworkers recently demonstrated that myxovirus resistance $2(\mathrm{Mx} 2)$ is an IFN-induced inhibitor of HIV-1 infection that may act by inhibiting capsid-dependent nuclear import of subviral complexes. ${ }^{25}$ In vivo, clinical trials have consistently demonstrated modest anti-HIV activity of INFo. In 1990, clinical trials demonstrated that IFN alfa alone or in combination with zidovudine could decrease HIV-1 isolation and slow HIV disease progression. ${ }^{26}$ More recently, Asmuth and colleagues from the AIDS Clinical Trials Group A5192 team found that weekly PegIFN $\alpha-2 a(180 \mathrm{mcg})$ led to a median plasma HIV viral load decrease of $0.61 \log _{10}$ copies $/ \mathrm{mL}$ (90\% confidence interval: $0.20-1.18 \log _{10}$ copies $\left./ \mathrm{mL}\right){ }^{27}$

While the role of INF $\alpha$ remains under investigation in the effort to cure chronic HIV infection, its utility in the treatment of chronic HCV infection has been limited by multiple factors including (1) Adverse effects that restrict patient eligibility for its use in all patient populations, and (2) impaired antiviral response in patients with HIV/HCV coinfection compared with those with HCV alone. First, at doses used to treat hepatitis C infection, INFo is associated with fatigue, depression, and bone marrow suppression, leading to lymphopenia and neutropenia as well as a myriad of other side effects. ${ }^{28}$ Not unexpectedly, many patients with HIV/HCV coinfection have medical and/or psychiatric contraindications to the use of INF $\alpha$. For example, in an examination of the United States Veterans Affairs Clinical Case Registry, only 35\% of HCVinfected patients were deemed eligible for IFN-based treatment and only $\sim 7 \%$ of HIV/HCV coinfected patients had received treatment. ${ }^{14,15}$ Second, INF $\alpha$ therapy appears to be less effective for the treatment of HCV in patients with HIV infection compared with those with $\mathrm{HCV}$ alone. In studies of HCV kinetics with INF $\alpha$ therapy, Sherman and colleagues found that after 48 weeks of treatment HCV RNA level was undetectable at 72 weeks in $25 \%$ and $40 \%$ of $\mathrm{HIV} / \mathrm{HCV}$ coinfected and HCV monoinfected patients, respectively. ${ }^{29}$ The researchers reported that HIV infection was associated with prolonged viral clearance and that the basis of this delayed HCV clearance was due primarily to higher levels of HCV RNA at baseline in coinfected patients compared with monoinfected patients.

The observation that HIV-infected patients have higher levels of HCV RNA than HIV-uninfected patients is well established. Indeed, as early as 1994, Eyster and coworkers observed that HCV RNA levels increased in men with hemophilia following HIV seroconversion and multiple studies of patients with chronic HCV infection have demonstrated that those with HIV coinfection have higher levels of hepatitis $C$ viremia compared with those without HIV. ${ }^{30-32}$ Recently, Balagopal and colleagues demonstrated that the level of HCV RNA decreased following the initiation of antiretroviral therapy in 19 patients with untreated HIV infection who had a median (range) CD4+ T lymphocyte count and HIV RNA level at baseline were 425 cells/ $/ \mu \mathrm{L}(219-690)$ and $4.27 \log 10 \mathrm{cp} / \mathrm{mL}$ (2.91-5.44), respectively. The researchers observed two distinct phases. In the first 12 weeks following initiation of antiretrovirals, HCV RNA levels increased in 18 of 19 patients (94.7\%) by a median of $0.28 \log 10 \mathrm{IU} / \mathrm{mL}$. However, after a median of 175 days of antiretroviral therapy, HCV RNA levels decreased to a level below baseline in 16 of 19 (84.2\%). The absolute within-individual decline from baseline in HCV RNA was modest (median change in HCV RNA, - $0.21 \log 10 \mathrm{IU} / \mathrm{mL}$ ). Interestingly, the decline in HCV RNA was closely associated with change in expression of several hepatic IFN-sensitive genes (ISGs) including among others, IFIT1 and IFIT2. ${ }^{33}$ This observation points toward a direct or indirect effect of HIV infection on the mechanism for control of $\mathrm{HCV}$ replication and support treatment with antiretroviral therapy in most HIV/ HCV coinfected patients.

While interesting, the effect of HIV treatment on HCV RNA levels is modest and the impact of high HCV RNA on response to INF $\alpha$ therapy is also well established in patients taking concurrent antiretroviral therapy. In the APRICOT study, HIV/HCV coinfected patients were treated with PegIFN $\alpha-2 \mathrm{a}$ and a fixed dose of RBV ( $800 \mathrm{mg} / \mathrm{d})$ for 48 weeks. Coinfected 


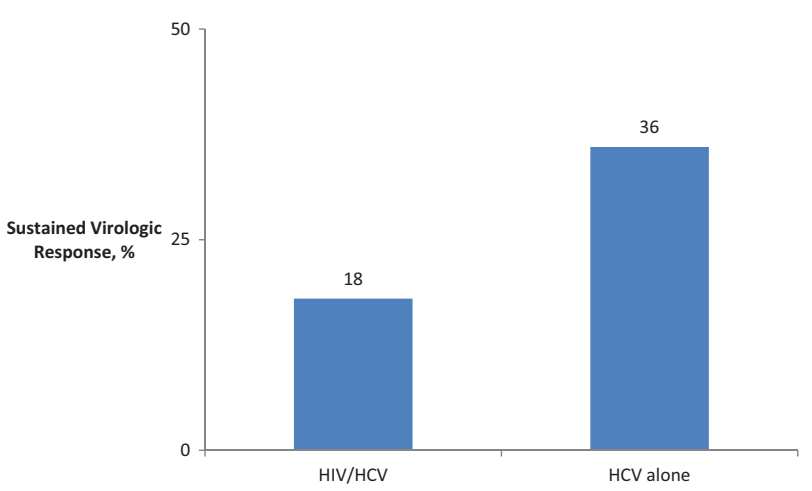

Fig. 1 Sustained virological response rate with peginterferon alfa-2a $180 \mu \mathrm{g}$ weekly plus ribavirin $800 \mathrm{mg}$ per day in human immunodeficiency virus-infected ${ }^{7}$ and uninfected patients ${ }^{34}$ with hepatitis $C$ virus (HCV) genotype 1 infection and high levels of HCV RNA level prior to treatment ( $>800,000$ copies/mL). ${ }^{7,34}$

patients with HCV RNA levels greater than 800,000 copies/mL prior to treatment had a sustained virologic response rate of $18 \%$ (23 of 130 patients); in contrast, those with HCV RNA levels less than 800,000 copies/mL prior to treatment had a sustained virologic response rate of $61 \%$ (28 of 46 patients). ${ }^{7}$ By comparison, in the study by Hadziyannis and colleagues, HCV monoinfected patients were treated with the same regimen, PegIFN $\alpha-2 a$ and fixed-dose RBV (800 mg/d) for 48 weeks. Monoinfected patients with HCV RNA levels greater than 800,000 copies/mL prior to treatment had a sustained virologic response rate of $36 \%$; in contrast, those with HCV RNA levels less than 800,000 copies/mL prior to treatment had a sustained virologic response rate of $55 \% .{ }^{34}$ In this crossstudy comparison of patients with high HCV RNA levels, the efficacy of PegIFN-based therapy was markedly lower in patients with HIV/HCV coinfection (18\%) compared with HCV monoinfection (36\%) (-Fig. 1).
Taken together, low rates of INF $\alpha$ eligibility and reduced efficacy have led to markedly limited effectiveness of IFNbased therapies in HIV/HCV coinfected patients. For example, in the Johns Hopkins HIV clinic, less than $1 \%$ of 845 HIV/HCV coinfected patients engaged in HIV care had achieved sustained virologic response. ${ }^{13}$ As such, strategies with antiviral agents that directly target the hepatitis $C$ virus are urgently needed to increase the rate of sustained virologic response. Although the removal of INF $\alpha$ will be necessary to increase the proportion of $\mathrm{HIV} / \mathrm{HCV}$ coinfected patients who are willing and able to undergo HCV treatment, the addition of highly active, oral HCV direct acting antivirals to PegIFN plus $\mathrm{RBV}$ in an important step toward IFN-free regimens.

\section{Similar Antiviral Contribution of Oral Direct Acting Antivirals to Peginterferon/Ribavirin in Patients with and without HIV Infection}

Antiviral agents that directly target HCV have shown great promise for the treatment of HIV/HCV coinfected patients (-Table 1). To date, multiple studies have been reported for the treatment of HCV genotype 1 infection in HIV-infected patients with PegIFN plus RBV in combination with a single direct acting antiviral agent, including NS3/4A protease inhibitors such as telaprevir, boceprevir, simeprevir, and the nucleotide analogue NS5B polymerase inhibitor, sofosbuvir. $^{35,36}$ Although in some cases, these data are preliminary in nature, the observed sustained virologic response rates in patients with HIV infection are similar to those observed in patients without HIV infection who were treated with the same HCV regimen. In the study of telaprevir plus PegIFN and RBV for the treatment of HCV genotype 1 infection in patients with HIV infection, sustained virologic response occurred in $74 \%$ (28 in 38 patients). ${ }^{36}$ In a separate study of telaprevir plus PegIFN and RBV for the treatment of HCV genotype 1 infection in patients without HIV infection, sustained virologic

Table 1 Sustained virological response for oral direct-acting antiviral regimens for the treatment of HCV genotype 1 infection in HIVinfected adults

\begin{tabular}{|l|l|l|l|l|}
\hline $\begin{array}{l}\text { Direct acting anti- } \\
\text { viral agent (Oral) }\end{array}$ & $\begin{array}{l}\text { Peginterferon } \\
\text { (Subcutaneous } \\
\text { injection) }\end{array}$ & Ribavirin (Oral) & Regimen duration & $\begin{array}{l}\text { Sustained virological } \\
\text { response (\%, } n \text { of } N \text { ) }\end{array}$ \\
\hline $\begin{array}{l}\text { Telaprevir } 750 \mathrm{mg} \\
\text { every } 8 \mathrm{~h}^{36}\end{array}$ & Alfa-2a $180 \mu \mathrm{g} / \mathrm{wk}$ & 1000 or $1200 \mathrm{mg} / \mathrm{d}$ & $\begin{array}{l}48 \text { wks (telaprevir for } \\
\text { the initial } 12 \text { wks only) }\end{array}$ & $74 \%(28$ of 38$)$ \\
\hline $\begin{array}{l}\text { Boceprevir } 800 \mathrm{mg} \\
\text { every } 8 \mathrm{~h}^{35}\end{array}$ & Alfa-2b $1.5 \mu \mathrm{g} / \mathrm{kg} / \mathrm{wk}$ & Ribavirin $600-1400 \mathrm{mg} / \mathrm{d}$ & $\begin{array}{l}48 \text { wks }(48 \mathrm{wks} \text { for } \\
\text { peginterferon and ribavirin; } \\
44 \text { wks for boceprevir) }\end{array}$ & $63 \%$ (40 of 64$)$ \\
\hline $\begin{array}{l}\text { Simeprevir } 150 \mathrm{mg} \\
\text { once daily } 37\end{array}$ & Alfa-2a $180 \mu \mathrm{g} / \mathrm{wk}$ & 1000 or $1200 \mathrm{mg} / \mathrm{d}$ & $\begin{array}{l}24 \text { or } 48 \text { wks based on } \\
\text { HCV RNA response at } \\
\text { treatment week } 4 \\
\text { (simeprevir for the initial } \\
12 \text { wks only) }\end{array}$ & $79 \%$ (42 of 53$)$ \\
\hline $\begin{array}{l}\text { Sofosbuvir } 400 \mathrm{mg} \\
\text { once daily } 40\end{array}$ & Alfa-2a $180 \mu \mathrm{g} / \mathrm{wk}$ & 1000 or $1200 \mathrm{mg} / \mathrm{d}$ & 12 wks (all drugs) & $89 \%$ (17 of 19) \\
\hline $\begin{array}{l}\text { Sofosbuvir } 400 \mathrm{mg} \\
\text { once daily } 41\end{array}$ & None & 1000 or $1200 \mathrm{mg} / \mathrm{d}$ & 24 wks (all drugs) & $76 \%$ (87 of 114) \\
\hline
\end{tabular}

Abbreviations: HCV, hepatitis C virus; HIV, human immunodeficiency virus. 
response occurred in $75 \%$ (271 of 365 patients). ${ }^{19}$ Similarly, for the regimen of boceprevir in combination with PegIFN and $\mathrm{RBV}$, the sustained virologic response rate in patients with HCV genotype 1 /HIV coinfection was $63 \%$ (40 of 64 patients). In the study of boceprevir plus PegIFN and RBV by Poordad and colleagues, the corresponding sustained virologic response rate in persons with HCV genotype 1 infection alone was $68 \%$ ( 213 of the 311 patients). ${ }^{20}$

The combination of simeprevir plus PegIFN and RBV has also been investigated in patients with and without HIV infection. In a study of 106 patients with HIV and HCV genotype 1 coinfection treated with this regimen, the overall sustained virologic response rate was $74 \%$ and, among those who had not undergone prior HCV treatment (naïve), the efficacy was $79 \%{ }^{37}$ In two studies of HIV uninfected persons with HCV genotype 1 infection who were treatment naive, the regimen of simeprevir plus PegIFN and RBV led to sustained virologic response in $80 \%$ of patients. ${ }^{38,39}$ Finally, in a small study of sofosbuvir plus PegIFN and RBV conducted by Rodriguez-Torres and coworkers in the Commonwealth of Puerto Rico, 23 patients with HIV and HCV genotype 1 $(n=19), 2(n=1), 3(n=2)$, and $4(n=1)$, coinfection was treated with this regimen for 12 weeks. The overall rate of sustained virologic response was $91 \%$, including 17 of $19(89 \%)$ of patients infected with HCV genotype $1 .^{40}$ This regimen of sofosbuvir plus PegIFN and RBV was also studied by Lawitz and colleagues in HIV-uninfected patients in the NEUTRINO study; in patients with HCV genotype 1 infection, the sustained virologic response rate was $89 \%{ }^{21}$

Although the studies of a single DAA plus PegIFN and RBV are relatively small and do not directly compare the efficacy in patients with or without HIV coinfection, the HCV treatment regimens have achieved similar efficacy in both patient populations. Indeed, the regulatory approvals in the United States and Europe of the nucleotide analogue NS5B polymerase inhibitor, sofosbuvir, provide labeling for the use of this agent in patients with HIV coinfection. Similarly, the regulatory approval in the United States (pending in Europe) of the HCV NS3/4A protease inhibitor, simeprevir, provides specific recommendations for drug interactions of this drug and commonly prescribed antiretroviral agents. Further, these data provide strong support for the hypothesis that oral, DAAs will have similar anti-HCV efficacy in the setting HIV infection and that the ability of the host to eradicate chronic $\mathrm{HCV}$ infection during antiviral treatment is not adversely impacted by the direct or indirect effects of HIV infection. Based on these promising results with INF $\alpha$, the removal of INF $\alpha$ from combination HCV treatment regimens is expected to increase patient eligibility for treatment as well as result in greater efficacy in the setting of high levels of HCV RNA.

\section{Encouraging Preliminary Data for Interferon-Free, Oral Direct Acting Antiviral Therapy in HIV-Infected Patients}

Adequate tests of the hypothesis that efficacy will be similar in patients with and without HIV infection will require large, adequately powered studies in both patient populations; at this time, many such studies have been initiated (-Table 2). To date, the PHOTON-1 study is the only IFN-free study to report sustained virologic response data. ${ }^{41}$ In this study, sofosbuvir and weight-based RBV were administered to 114 treatment-naïve patients with HCV genotype 1 for 24 weeks and 68 treatment-naive patients with HCV genotype 2 or 3 for 12 weeks. Among treatment-naïve patients with HIV infection, the sustained virologic response rates were $76 \%$ for patients with genotype 1 infection, $88 \%$ for patients with genotype 2 infection, and $67 \%$ for patients with genotype 3 infection. This same regimen, sofosbuvir plus weight based RBV for 12 or 24 weeks, has also been studied in HIV-uninfected patients in two different studies. $^{21,42}$ For HIV-uninfected patients with HCV genotype 1 infection in the SPARE study, Osinusi and coworkers reported that $68 \%$ of patients treated with sofosbuvir and weight-based RBV for 24 weeks achieved sustained virologic response. ${ }^{42}$ Similarly, in the FISSION study, Lawitz and colleagues reported that sustained virologic response occurred in $97 \%$ of patients with genotype 2 and in 56\% of those with genotype 3 treated with sofosbuvir and weightbased RBV for 12 weeks. $^{21}$

Table 2 Clinical trials of Interferon-free, oral direct-acting antiviral regimens for the treatment of HCV infection in HIV-infected adults

\begin{tabular}{|c|c|c|c|c|c|}
\hline \multicolumn{5}{|c|}{$\mathrm{HCV}$ treatment regimen } & \multirow{2}{*}{$\begin{array}{l}\text { ClinicalTrials.gov } \\
\text { identifier }\end{array}$} \\
\hline $\begin{array}{l}\text { NS3/4A } \\
\text { protease } \\
\text { inhibitor }\end{array}$ & NS5A inhibitor & $\begin{array}{l}\text { NS5B nucleotide } \\
\text { analogue polymerase } \\
\text { inhibitor }\end{array}$ & $\begin{array}{l}\text { NS5B } \\
\text { non-nucleoside } \\
\text { analogue polymerase } \\
\text { inhibitor }\end{array}$ & Ribavirin & \\
\hline None & Ledipasvir & Sofosbuvir & None & None & NCT01878799 \\
\hline None & Daclatasvir & Sofosbuvir & None & None & NCT02032888 \\
\hline $\begin{array}{l}\text { ABT450/ } \\
\text { ritonavir }\end{array}$ & ABT267 & None & ABT333 & 1000 or $1200 \mathrm{mg} / \mathrm{d}$ & NCT01939197 \\
\hline MK-5172 & MK-8742 & None & None & 1000 or $1200 \mathrm{mg} / \mathrm{d}$ & NCT01717326 \\
\hline
\end{tabular}

Abbreviations: HCV, hepatitis C virus; HIV, human immunodeficiency virus. 
Additional studies of IFN-free, oral DAAs for the treatment of HCV in HIV-infected patients are underway. At the National Institute of Allergy and Infectious Diseases (NIAID), the combination of sofosbuvir and the HCV NS5A inhibitor, ledipasvir, is being evaluated in 100 patients with HIV and HCV genotype 1 coinfection who are not being treated for HIV infection (CD4 $>500$ cells $/ \mathrm{mm}^{3}$ ) or who have suppressed HIV-1 RNA on antiretroviral therapy regimens consisting of medications from the following: tenofovir, emtricitabine, efavirenz, raltegravir, and rilpivirine (ClinicalTrials.gov Identifier: NCT01878799). Similarly, in the ALLY-2 study, HIVinfected patients who are chronically infected with HCV genotype $1,2,3,4,5$, or 6 are being treated with the combination of the sofosbuvir and the HCV NS5A inhibitor, daclatasvir, for 8 or 12 weeks (ClinicalTrials.gov Identifier: NCT02032888). Also underway is the TURQUOISE-I study, which will evaluate the safety and efficacy of the coformulated ritonavir-boosted HCV NS3/4A protease inhibitor, ABT450, and the HCV NS5A inhibitor, ABT-267 (ABT-450/r/ABT267), in combination with the HCV NS5B nonnucleoside polymerase inhibitor, ABT-333, and RBV in HIV-infected patients with HCV genotype 1 infection (ClinicalTrials.gov Identifier: NCT01939197). Lastly, the C-WORTHY study is evaluating the safety and efficacy of the two-drug combination of the second-generation HCV NS3/4A protease inhibitor, MK-5172, plus the second-generation HCV NS5A inhibitor, MK-8742, with or without RBV in HCV genotype 1 infected patients with and without HIV coinfection (ClinicalTrials.gov Identifier: NCT01717326). Interesting, the C-WORTHY study is enrolling both patient populations-HIV-infected and uninfected patients-in the same HCV study protocol. This study design underscores the emerging recognition that HIV-infected patients may not be unique in terms of the effectiveness of oral, IFN-free DAA regimens.

\section{Conclusions}

Multiple IFN-free clinical trials are underway in persons with HIV/HCV coinfection; these studies are anticipated to demonstrate that oral, DAAs for HCV have similar efficacy in patients with and without HIV coinfection, lending additional support to the hypothesis that HIV coinfection does not adversely impact the effectiveness of these highly active HCV treatments. If, as expected, these studies yield high rates of sustained virologic response with acceptable safety and tolerability profiles, the remaining challenge to the management of HCV infection in persons with HIV coinfection will be the need to carefully consider the potential drug interactions between the patient's antiretroviral drug regimen and the HCV DAA drug regimen. ${ }^{43-45}$ For some patient's and some drug regimens, this may represent the combination of as many as 10 unique antiviral drugs each with a different mechanism of action to inhibit HIV or HCV or to block antiviral drug metabolism through inhibition of the patient's cytochrome P450 pathways with pharmacologic enhancers, such as ritonavir or cobicistat. ${ }^{46,47}$

Full understanding of the potential for drug interactions between highly active drug regimens for the treatment of $\mathrm{HCV}$ and HIV is required before these regimens can be safely combined for routine use in clinical practice. Indeed, due to complex drug interactions with some antiviral agents, the expectation is that not all antiretroviral regimens will be able to be safely combined with all HCV DAA regimens; as such, clinicians who treat patients with HIV/HCV coinfection will need to carefully select the most appropriate HIV and HCV treatment regimens for each patient. However, it is important to recognize that HCV treatment is finite, leading to cure of the chronic HCV infection. ${ }^{48,49}$ Further, the anticipated duration of HCV treatment with oral DAAs will be only 12 or 24 weeks for most HIV/HCV coinfected patients. Accordingly, complex drug interactions will not be an insurmountable barrier to HCV eradication for patients with HIV coinfection. Of course, the availability of safe and effective oral HCV DAAs is merely the first step toward controlling HCV disease in HIV-infected patients; comprehensive strategies to effectively and economically deliver these HCV treatments to the nearly 5 million patients with HIV/HCV coinfection worldwide will be critical to effectively address this curable, life-threatening infection. ${ }^{50}$

\section{Acknowledgments}

Financial support came from grants K24DA034621 and R01DA16065 from the National Institute on Drug Abuse (NIDA) and UL1RR025005 from the National Center for Research Resources (NCRR), components of the National Institutes of Health (NIH) and NIH Roadmap for Medical Research.

\section{References}

1 van der Helm J, Geskus R, Sabin C, et al; CASCADE Collaboration in EuroCoord. Effect of HCV infection on cause-specific mortality after HIV seroconversion, before and after 1997. Gastroenterology 2013;144(4):751-760, e2

2 Wandeler G, Gsponer T, Bregenzer A, et al; Swiss HIV Cohort Study. Hepatitis $C$ virus infections in the Swiss HIV Cohort Study: a rapidly evolving epidemic. Clin Infect Dis 2012;55(10):1408-1416

3 Kirk GD, Mehta SH, Astemborski J, et al. HIV, age, and the severity of hepatitis $C$ virus-related liver disease: a cohort study. Ann Intern Med 2013;158(9):658-666

4 Ly KN, Xing J, Klevens RM, Jiles RB, Ward JW, Holmberg SD. The increasing burden of mortality from viral hepatitis in the United States between 1999 and 2007. Ann Intern Med 2012;156(4): 271-278

5 Kaplan JE, Benson C, Holmes KK, et al; Centers for Disease Control and Prevention (CDC); National Institutes of Health; HIV Medicine Association of the Infectious Diseases Society of America. Guidelines for the prevention and treatment of opportunistic infections in HIV-infected adults and adolescents: recommendations from the Centers for Disease Control and Prevention, the National Institutes of Health, and the HIV Medicine Association of the Infectious Diseases Society of America. MMWR Recomm Rep 2009;58(RR-4):1-207; quiz CE1-4

6 Rockstroh JK, Bhagani S, Benhamou Y, et al; EACS Executive Committee. European AIDS Clinical Society (EACS) guidelines for the clinical management and treatment of chronic hepatitis $B$ and C coinfection in HIV-infected adults. HIV Med 2008;9(2):82-88

7 Torriani FJ, Rodriguez-Torres M, Rockstroh JK, et al; APRICOT Study Group. Peginterferon Alfa-2a plus ribavirin for chronic hepatitis $C$ virus infection in HIV-infected patients. N Engl J Med 2004;351(5): $438-450$ 
8 Chung RT, Andersen J, Volberding P, et al; AIDS Clinical Trials Group A5071 Study Team. Peginterferon Alfa-2a plus ribavirin versus interferon alfa-2a plus ribavirin for chronic hepatitis C in HIVcoinfected persons. N Engl J Med 2004;351(5):451-459

9 Rodriguez-Torres M, Slim J, Bhatti L, et al. Peginterferon alfa-2a plus ribavirin for HIV-HCV genotype 1 coinfected patients: a randomized international trial. HIV Clin Trials 2012;13(3):142-152

10 Limketkai BN, Mehta SH, Sutcliffe CG, et al. Relationship of liver disease stage and antiviral therapy with liver-related events and death in adults coinfected with HIV/HCV. JAMA 2012;308(4): 370-378

11 Berenguer J, Alvarez-Pellicer J, Martín PM, et al; GESIDA3603/5607 Study Group. Sustained virological response to interferon plus ribavirin reduces liver-related complications and mortality in patients coinfected with human immunodeficiency virus and hepatitis C virus. Hepatology 2009;50(2):407-413

12 Mehta SH, Genberg BL, Astemborski J, et al. Limited uptake of hepatitis $C$ treatment among injection drug users. J Community Health 2008;33(3):126-133

13 Mehta SH, Lucas GM, Mirel LB, et al. Limited effectiveness of antiviral treatment for hepatitis $\mathrm{C}$ in an urban HIV clinic. AIDS 2006;20(18):2361-2369

14 Butt AA, Justice AC, Skanderson M, Good C, Kwoh CK. Rates and predictors of hepatitis $C$ virus treatment in HCV-HIV-coinfected subjects. Aliment Pharmacol Ther 2006;24(4):585-591

15 Kramer JR, Kanwal F, Richardson P, Mei M, El-Serag HB. Gaps in the achievement of effectiveness of HCV treatment in national VA practice. J Hepatol 2012;56(2):320-325

16 Naggie S, Sulkowski MS. Management of patients coinfected with HCV and HIV: a close look at the role for direct-acting antivirals. Gastroenterology 2012;142(6):1324-1334, e3

17 Cacoub P, Rosenthal E, Halfon P, Sene D, Perronne C, Pol S. Treatment of hepatitis $C$ virus and human immunodeficiency virus coinfection: from large trials to real life. J Viral Hepat 2006;13(10):678-682

18 McGowan CE, Monis A, Bacon BR, et al. A global view of hepatitis C: physician knowledge, opinions, and perceived barriers to care. Hepatology 2013;57(4):1325-1332

19 Jacobson IM, McHutchison JG, Dusheiko G, et al; ADVANCE Study Team. Telaprevir for previously untreated chronic hepatitis $C$ virus infection. N Engl J Med 2011;364(25):2405-2416

20 Poordad F, McCone J Jr, Bacon BR, et al; SPRINT-2 Investigators. Boceprevir for untreated chronic HCV genotype 1 infection. N Engl J Med 2011;364(13):1195-1206

21 Lawitz E, Mangia A, Wyles D, et al. Sofosbuvir for previously untreated chronic hepatitis C infection. N Engl J Med 2013; 368(20):1878-1887

22 Jacobson IM, Gordon SC, Kowdley KV, et al; POSITRON Study; FUSION Study. Sofosbuvir for hepatitis C genotype 2 or 3 in patients without treatment options. N Engl J Med 2013;368(20): 1867-1877

23 Sulkowski MS, Gardiner DF, Rodriguez-Torres M, et al; AI444040 Study Group. Daclatasvir plus sofosbuvir for previously treated or untreated chronic HCV infection. N Engl J Med 2014;370(3):211-221

24 Kowdley KV, Lawitz E, Poordad F, et al. Phase 2b trial of interferonfree therapy for hepatitis C virus genotype 1. N Engl J Med 2014; 370(3):222-232

25 Kane M, Yadav SS, Bitzegeio J, et al. MX2 is an interferon-induced inhibitor of HIV-1 infection. Nature 2013;502(7472):563-566

26 Lane HC, Davey V, Kovacs JA, et al. Interferon-alpha in patients with asymptomatic human immunodeficiency virus (HIV) infection. A randomized, placebo-controlled trial. Ann Intern Med 1990;112(11):805-811

27 Asmuth DM, Murphy RL, Rosenkranz SL, et al; AIDS Clinical Trials Group A5192 Team. Safety, tolerability, and mechanisms of antiretroviral activity of pegylated interferon Alfa-2a in HIV-1-monoinfected participants: a phase II clinical trial. J Infect Dis 2010; 201(11):1686-1696
28 Sulkowski MS, Cooper C, Hunyady B, et al. Management of adverse effects of Peg-IFN and ribavirin therapy for hepatitis C. Nat Rev Gastroenterol Hepatol 2011;8(4):212-223

29 Sherman KE, Shire NJ, Rouster SD, et al. Viral kinetics in hepatitis C or hepatitis $\mathrm{C} /$ human immunodeficiency virus-infected patients. Gastroenterology 2005;128(2):313-327

30 Eyster ME, Fried MW, Di Bisceglie AM, Goedert JJ. Increasing hepatitis C virus RNA levels in hemophiliacs: relationship to human immunodeficiency virus infection and liver disease. Multicenter Hemophilia Cohort Study. Blood 1994;84(4):1020-1023

31 Daar ES, Lynn H, Donfield S, et al; Hemophilia Growth and Development Study. Hepatitis C virus load is associated with human immunodeficiency virus type 1 disease progression in hemophiliacs. J Infect Dis 2001;183(4):589-595

32 Thomas DL, Shih JW, Alter HJ, et al. Effect of human immunodeficiency virus on hepatitis $C$ virus infection among injecting drug users. J Infect Dis 1996;174(4):690-695

33 Balagopal A, et al. Antiretroviral therapy, Interferon Sensitivity, and Virologic Set Point in HIV-Hepatitis C Virus Co-infected Patients. Hepatology 2014; In press

34 Hadziyannis SJ, Sette H Jr, Morgan TR, et al; PEGASYS International Study Group. Peginterferon-alpha2a and ribavirin combination therapy in chronic hepatitis $\mathrm{C}$ : a randomized study of treatment duration and ribavirin dose. Ann Intern Med 2004;140(5): 346-355

35 Sulkowski M, Pol S, Mallolas J, et al; P05411 study investigators. Boceprevir versus placebo with pegylated interferon alfa- $2 \mathrm{~b}$ and ribavirin for treatment of hepatitis $C$ virus genotype 1 in patients with HIV: a randomised, double-blind, controlled phase 2 trial. Lancet Infect Dis 2013;13(7):597-605

36 Sulkowski MS, Sherman KE, Dieterich DT, et al. Combination therapy with telaprevir for chronic hepatitis $C$ virus genotype 1 infection in patients with HIV: a randomized trial. Ann Intern Med 2013;159(2):86-96

37 Dieterich DT, et al. Simeprevir (TMC435) plus peginterferon/ ribavirin in patients co-infected with HCV genotype- 1 andHIV1: primary analysis of the C212 study. 14th European AIDs Conference (EACS 2013). Brussels. October 16-19, 2013. Abstract PS9/5.

38 Jacobson I, et al. Simeprevir (TMC435) with peginterferon/ribavirin for chronic HCV genotype-1 infection in treatment-naïve patients: results from QUEST-1, a phase III trial. Paper presented at: 48th Annual Meeting of the European Association for the Study of the Liver; April 24-28, 2013; Amsterdam, Netherlands

39 Manns M, et al. Simeprevir (TMC435) with peginterferon/ribavirin for chronic HCV genotype-1 infection $n$ treatment-naïve patients: results from QUEST-2, a phase III trial. Paper presented at: 48th Annual Meeting of the European Association for the Study of the Liver; April 24-28, 2013; Amsterdam, Netherlands

40 Rodriguez-Torres M, et al. Sofosbuvir and peginterferon alfa-2a/ ribavirin for treatment-naïve genotype 1-4 HCV infected patients who are HIV coinfected with HIV. Paper presented at: ID Week 2013; October 2-6, 2013; San Francisco, CA

41 Sulkowski MS, et al. All-oral therapy with sofosbuvir plus ribavirin for the treatment of HCV genotype 1, 2, and 3 infection in patients co-infected with HIV (PHOTON-1). Paper presented at: The 64th Annual Meeting of the American Association for the Study of Liver Diseases; November 1-5, 2013; Washington, DC

42 Osinusi A, Meissner EG, Lee YJ, et al. Sofosbuvir and ribavirin for hepatitis $C$ genotype 1 in patients with unfavorable treatment characteristics: a randomized clinical trial. JAMA 2013;310(8): 804-811

43 van Heeswijk RP, Beumont M, Kauffman RS, Garg V. Review of drug interactions with telaprevir and antiretrovirals. Antivir Ther 2013; 18(4):553-560

44 Seden K, Back D, Khoo S. Antiretroviral drug interactions: often unrecognized, frequently unavoidable, sometimes unmanageable. J Antimicrob Chemother 2009;64(1):5-8 
45 Wilby KJ, Greanya ED, Ford JA, Yoshida EM, Partovi N. A review of drug interactions with boceprevir and telaprevir: implications for HIV and transplant patients. Ann Hepatol 2012;11(2):179-185

46 Deeks ED. Cobicistat: a review of its use as a pharmacokinetic enhancer of atazanavir and darunavir in patients with HIV-1 infection. Drugs 2013

47 Asselah T. ABT-450 combined with ritonavir, in addition to ABT333 and ribavirin: a race for an interferon-free regimen to cure HCV infection. J Hepatol 2013;59(4):885-888
48 Schmidt WN, Nelson DR, Pawlotsky JM, Sherman KE, Thomas DL, Chung RT. Direct-acting antiviral agents and the path to interferon independence. Clin Gastroenterol Hepatol 2013

49 Thomas DL, Leoutsakas D, Zabransky T, Kumar MS. Hepatitis C in HIV-infected individuals: cure and control, right now. J Int AIDS Soc 2011;14:22

50 von Schoen-Angerer T, Cohn J, Swan T, Piot P. UNITAID can address HCV/HIV co-infection. Lancet 2013;381(9867):628 